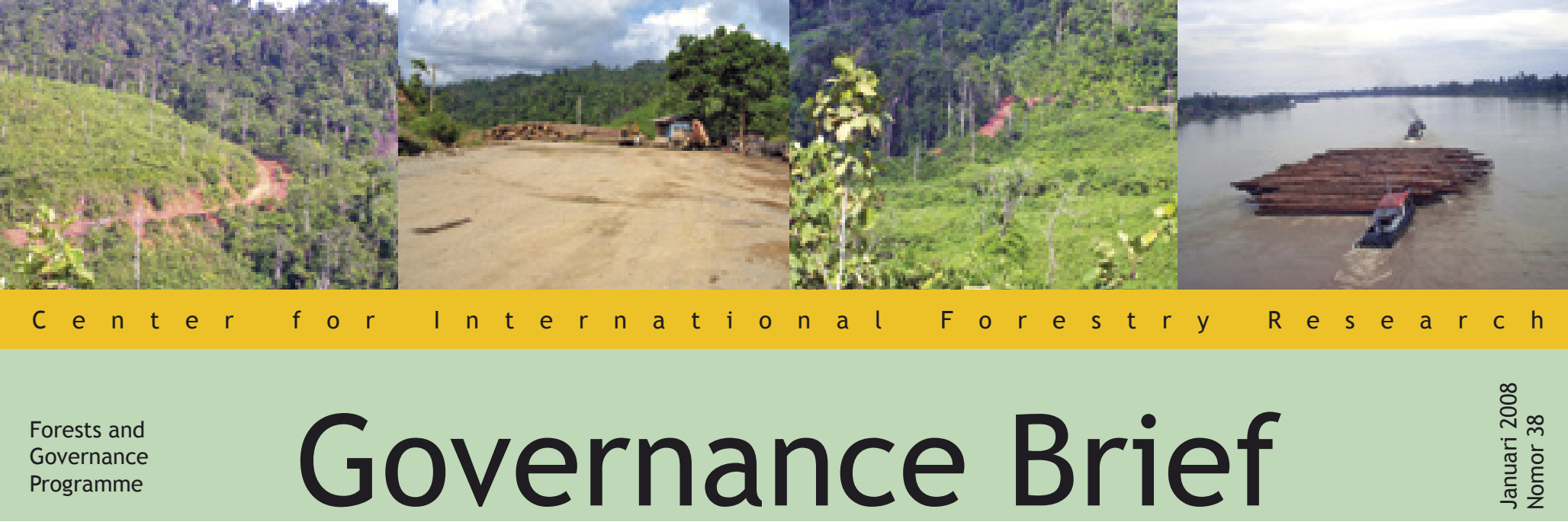

\title{
Menerawang Kesatuan Pengelolaan Hutan di Era Otonomi Daerah
}

\author{
Putu Oka Ngakan, Heru Komarudin dan Moira Moeliono
}

\begin{abstract}
Sejak diterapkannya sistem pemerintahan otonomi daerah (otoda), pembangunan dan pengelolaan hutan menghadapi berbagai tantangan baru. Lahirnya UU No 41/1999 tentang Kehutanan yang kurang mengikutsertakan pemerintah daerah dalam pengurusan hutan ditanggapi berbagai pihak sebagai tidak sejalan dengan penyelenggaraan otonomi daerah. Pemerintah pusat dianggap mendominasi pengambilan keputusan dalam pengelolaan hutan. Namun, di sisi lain ketika kabupaten beserta masyarakatnya diberikan kesempatan yang lebih luas untuk mengelola hutan yang ada di wilayahnya, di beberapa daerah terjadi ledakan pemberian izin konsesi skala kecil yang mengakibatkan meningkatnya laju kerusakan hutan.
\end{abstract}

Dalam melaksanakan misi pengurusan hutan di era otoda, pemerintah pusat meluncurkan berbagai kebijakan yang diharapkan dapatmendorong terwujudnya kelestarian hutan dan kesejahteraan masyarakat, serta sekaligus mengakomodir tuntutan dan kepentingan pemerintah daerah. Salah satu kebijakan yang sedang dikembangkan adalah apa yang tertuang dalam PP No 6/2007' yakni Kesatuan Pengelolaan Hutan (KPH). Badan Planologi Departemen Kehutanan (2006) menyatakan bahwa pembentukan KPH bertujuan untuk menyediakan wadah bagi terselenggaranya kegiatan pengelolaan hutan secara efisien dan lestari. Sepintas, konsep ini nampak cukup menjanjikan terwujudnya pengelolaan hutan secara lebih bertanggung gugat dan lestari di masa yang akan datang. Namun, jika diterawang secara lebih jauh serta dikaitkan dengan peran dan keterlibatan pemerintah daerah dalam pengelolaan hutan, masih cukup banyak pertanyaan yang belum dapat dijawab secara tegas. Misalnya menyangkut kelembagaan dan pembagian tugas dan fungsi terkait dengan lembaga kehutanan yang sudah ada saat ini, pendanaan operasional terkait dengan sistem perimbangan keuangan, perwilayahan $\mathrm{KPH}$ dan organisasinya.

Tulisan ini mengkaji konsep KPH dari beberapa aspek seperti hubungan kewenangan, kelembagaan, organisasi, operasional, perwilayahannya dan tanggapan daerah. Tujuannya adalah untuk mengetahui hal-hal yang harus dibenahi agar konsep KPH benar-benar dapat diterapkan dan mencapai tujuan sesuai yang diharapkan. 


\section{Selayang pandang KPH}

$\mathrm{KPH}$ merupakan konsep perwilayahan pengelolaan hutan sesuai dengan fungsi pokok dan peruntukannya, yang dapat dikelola secara efisien dan lestari. Konsep KPH sebenarnya mulai diwacanakan sejak diberlakukannya UU No. 5/1967², yang pada masa itu diartikan sebagai Kesatuan Pemangkuan Hutan, sebagaimana diterapkan dalam pengelolaan hutan oleh Perum Perhutani di Pulau Jawa. Dalam UU 41/1999³ konsep ini kembali dimunculkan yang kemudian diikuti dengan aturan pedoman pembentukannya seperti tertuang dalam beberapa peraturan perundangundangan. Sebelumnya pada awal tahun 1990an, keluar beberapa peraturan menteri yang mengatur Kesatuan Pengusahaan Hutan Produksi atau KPHP yang konsepnya adalah juga pengelolaan hutan lestari.

Dalam perkembangannya di luar Jawa, KPH juga pernah diujicobakan, baik dalam konteks "pengusahaan" maupun "pengelolaan". Sekitar tahun 1994-1998, misalnya, beberapa pihak melakukan inisiatif bekerjasama dengan Departemen Kehutanan untuk membangun model pengelolaan hutan lestari ${ }^{4}$. Namun, tidak terlalu jelas sejauh mana hasil dari inisiatif tersebut menjadi bahan masukan bagi kebijakan nasional dan pembelajaran bagi daerah lain, karena tidak terlihat diikuti dengan implementasi nyata di lapangan. Rekomendasi kebijakan rasional yang cenderung menuntut perubahan drastis di dalam pengelolaan sumberdaya hutan, misalnya mengubah status quo terkait dengan $\mathrm{HPH}^{5}$, tampaknya membuat enggan pihak pembuat kebijakan untuk mengadopsi model tersebut lebih jauh.

Dari beberapa kebijakan pemerintah yang menjabarkan lebih jauh mengenai konsep $\mathrm{KPH}$, terdapat perbedaan yang cukup mengganggu tentang apa yang dimaksud KPH. Dalam PP 6/2007, $\mathrm{KPH}$ diartikan sebagai "wilayah pengelolaan hutan sesuai fungsi pokok dan peruntukannya, yang dapat dikelola secara efisien dan lestari". Namun dalam sebuah keputusan Menteri Kehutanan', $\mathrm{KPH}$ diartikan sebagai "unit pengelolaan hutan "terkecil" sesuai fungsi pokok ... dan seterusnya". Adanya kata "terkecil" tersebut cukup mengganggu pemahaman tentang pengertianyang sesungguhnya dari KPH, khususnya jika dikaitkan dengan institusi pengelolanya dan kemampuan institusi tersebut.

Badan Planologi Departemen Kehutanan (2006) menyebutkan $\mathrm{KPH}$ sebagai "unit pengelolaan hutan". Walaupun antara kata "kesatuan" dan "unit" memiliki makna yang sama, namun penggunaannya dalam konteks yang berbeda cukup membingungkan, seperti pada penjelasan lebih lanjut yang menyatakan bahwa "wilayah pengelolaan hutan tingkat unit pengelolaan adalah kesatuan pengelolaan hutan terkecil". Jadi, yang mana dimaksud dengan terkecil? Apakah $\mathrm{KPH}$ itu sendiri atau ada unit-unit kecil di dalam sebuah wilayah KPH yang lebih luas. Ketidakseragaman istilah tersebut bukan saja menyulitkan pemahaman tentang konsep KPH itu sendiri, tetapi juga dapat menimbulkan permasalahan dalam pembentukan wilayah dan struktur organisasi pengelolaannya. Apabila KPH diartikan sebagai unit pengelolaan hutan terkecil sesuai fungsi pokoknya, maka satu wilayah kabupaten yang luas bisa mencakup beberapa $\mathrm{KPH}$ yang tentunya masing-masing disertai dengan struktur organisasinya. Hal ini akan menjadikan sistem pengelolaan hutan model $\mathrm{KPH}$ tidak efisien sehingga menyimpang dari tujuan pembentukannya. Selain itu, banyaknya KPH yang berupa unit-unit terkecil dalam satu wilayah kabupaten akan menyulitkan tata hubungan kerja antara unit-unit KPH dengan KPH tingkat kabupaten, tingkat provinsi dan tingkat pusat.

Badan Planologi Departemen Kehutanan (2006) lebih jauh menyatakan empat prinsip yang melandasi pembentukan wilayah $\mathrm{KPH}$, yaitu: (1) transparansi, (2) pelibatan penuh seluruh pihak terkait, (3) akuntabilitas dan (4) ekosistem. Mengacu pada prinsip yang terakhir muncul pertanyaan, apakah wilayah KPH akan ditetapkan mengikuti wilayah suatu ekosistem atau Daerah Aliran Sungai (DAS)? Pertanyaan ini sulit dijawab karena dalam aturan pembentukan wilayah KPH Produksi - keempat prinsip tersebut justru tidak dijadikan acuan.

Dari pernyataan yang berbunyi "sesuai dengan fungsi pokok dan peruntukannya" yang selalu menyertai definisi $\mathrm{KPH}$, nampaknya perwilayahan $\mathrm{KPH}$ akan dibuat dengan merujuk pada fungsi pokok dan peruntukan hutan yang sudah ada. Oleh karena itu, KPH diberi nama menurut kategori fungsi pokok dan peruntukannya seperti: KPHP ( $\mathrm{P}=$ Produksi), $\mathrm{KPHL}(\mathrm{L}=$ Lindung) dan KPHK (K= Konservasi).

Dalam rangka memberdayakan masyarakat di sekitar hutan, pemerintah dapat membentuk KPHKm (Km = Kemasyarakatan) atau KPHA (A = Adat) di dalam unit $\mathrm{KPH}$. KPHKm dan KPHA merupakan kawasan hutan yang pemanfaatannya diberikan kepada sekelompok masyarakat di sekitar hutan. Oleh karena berada dalam kawasan hutan, pengelolaan dan pemanfaatan hutan di wilayah KPHKm dan 
KPHA tidak boleh dilakukan menyimpang dari fungsi pokok dan peruntukan kawasan hutan dimana KPH tersebut berada. Demikian juga organisasinya tidak berdiri sendiri melainkan berada di bawah organisasi $\mathrm{KPH}$ yang mewilayahinya.

\section{Konsep KPH pada Era Otoda}

Ketika KPH muncul lagi dalam PP 6/2007 di saat era otoda, berbagai pihak di daerah mulai membicarakannya dan menyampaikan pandangan beragam. Sebagian kalangan beranggapan bahwa kebijakan tersebut merupakan tawaran pemerintah pusat kepada daerah seiring dengan desentralisasi yang lebih luas di sektor kehutanan. Kalangan tersebut beranggapan bahwa konsep $\mathrm{KPH}$ akan memberikan kesempatan kepada daerah untuk terlibat lebih banyak dalam menentukan bentuk dan perwilayahan pengelolaan hutan di daerahnya. Sebagian lagi melihat KPH sebagai instrumen sentralisasi yang tidak sejalan dengan otonomi daerah dimana pemerintah pusat akan mengendalikan kembali sepenuhnya pengelolaan hutan.

Pandangan bahwa KPH adalah instrumen sentralisasi tampaknya beralasan jika dikaitkan dengan besarnya wewenang pemerintah pusat dalam menetapkan luas wilayah dan pencadangan areal KPH. Namun demikian, jika kita lihat PP $6 / 2007$ secara lebih dalam, pemerintah daerah juga diberikan kewenangan yang cukup luas. Pasal 8, misalnya, menyiratkan bahwa organisasi KPHL dan KPHP dalam suatu wilayah kabupaten/ kota ditetapkan oleh pemerintah kabupaten/ kota bersangkutan, sedangkan organisasi KPHL dan KPHP lintas kabupaten kota ditetapkan oleh pemerintah provinsi. Dalam hal ini hak, wewenang dan kewajiban daerah otonom untuk mengatur dan mengurus sendiri urusan pemerintahan yang menjadi inti otoda tampaknya diberi tempat dalam pembentukan $\mathrm{KPH}$.

Selain itu, pemerintah daerah juga diberi kewenangan untuk mengeluarkan berbagai izin di seluruh kawasan hutan, seperti IUPK, IUPJL, IUPHHBK, dan IPHHK ${ }^{7}$. Bupati diberi kewenangan untuk mengeluarkan izin-izin tersebut dalam $\mathrm{KPH}$ yang berada dalam wilayah kabupaten, dan gubernur untuk KPH lintas kabupaten. Namun demikian, tentu saja baik pembentukan organisasi maupun pengeluaran izin didasarkan atas standar dan kriteria yang ditetapkan oleh pemerintah pusat, seperti yang juga disebutkan dalam PP 6/2007.
Dalam pemberian izin-izin tersebut, baik menteri, gubernur, maupun bupati harus menyampaikan tembusan kepada kepala KPH dan kepala pemerintahan pada tingkat yang berbeda. Lain halnya dengan izin-izin yang disebutkan sebelumnya, izin usaha Pemanfaatan Hasil Hutan Kayu atau IUPHHK hanya dapat dikeluarkan oleh menteri. Pelimpahan kewenangan kepada daerah untuk pengeluaran IUPHHK juga sebenarnya dimungkinkan, seperti yang diatur dalam satu pasal PP tersebut, tetapi pendekatan yang diterapkan adalah bertahap dan selektif. Artinya bahwa kewenangan tersebut hanya dapat diberikan kepada daerah yang sudah siap dari sisi kelembagaan dan visinya9 .

Pembagian urusan pemerintahan antar tingkat pemerintahan diaturlebih lanjut dalam PP 38/2007 ${ }^{10}$, yang diterbitkan tujuh bulan setelah PP 6/2007. Terkait dengan sub bidang kehutanan, khususnya Sub Bidang Pembentukan Wilayah Pengelolaan Hutan, pembagian urusan pemerintahan antara pemerintah pusat, provinsi dan kabupaten disarikan pada Tabel 1. Nampak bahwa kewenangan kabupaten dalam pembentukan wilayah $\mathrm{KPH}$ tidak lebih dari sekedar mengusulkan dan memberikan pertimbangan teknis. Padahal dalam salah satu Keputusan Menteri ${ }^{11}$ dinyatakan bahwa daerah membentuk KPHP berdasarkan arahan pencadangan KPHP yang ditetapkan oleh menteri.

Untuk aspek pembentukan organisasi dan institusi pengelola wilayah $\mathrm{KPH}$, kewenangan pemerintah kabupaten yang cukup luas diberikan dalam PP 6/2007 tampaknya dipersempit oleh PP 38/2007 yang hanya memberikan kewenangan untuk menyampaikan pertimbangan dan rekomendasi teknis dalam penetapan organisasi $\mathrm{KPH}$. Tampaknya disharmonisasi peraturan masih akan berlanjut dan berpeluang mempersulit koordinasi antara pemerintah pusat dan daerah dalam beberapa tahun mendatang. Yang menarik adalah bahwa PP 38/2007 yang membatasi kewenangan pemerintah kabupaten adalah justru merupakan aturan pelaksanaan dari UU 32/2004, sementara PP 6/2007 adalah aturan pelaksanaan dari UU 41/1999. Dengan demikian, anggapan bahwa konsep $\mathrm{KPH}$ akan memberikan daerah, khususnya kabupaten, kesempatan yang lebih luas dalam menentukan bentuk dan perwilayahan pengelolaan hutan di daerahnya sepertinya tidak akan terwujud.

Keberhasilan suatu strategi pengelolaan hutan akan sangat tergantung pada sejauhmana berbagai pihak yang berkepentingan mempunyai kewenangan dan peran yang wajar. Dalam era otoda, seyogyanya pemerintah daerah, khususnya kabupaten, 
Tabel 1. Matriks pembagian urusan pemerintahan terkait dengan $\mathrm{KPH}$ antara pemerintah pusat, provinsi, dan kabupaten disarikan dari PP 38/2007

\begin{tabular}{|c|c|c|c|}
\hline Urusan Pemerintahan & Pusat & Provinsi & Kabupaten \\
\hline 1. Rancang bangun & $\begin{array}{l}\text { Penetapan norma, } \\
\text { standar, prosedur dan } \\
\text { kriteria }\end{array}$ & $\begin{array}{l}\text { Pelaksanaan } \\
\text { penyusunan }\end{array}$ & $\begin{array}{l}\text { Pertimbangan } \\
\text { penyusunan }\end{array}$ \\
\hline $\begin{array}{l}\text { 2. Wilayah pengelolaan } \\
\text { hutan }\end{array}$ & Pelaksanaan penetapan & $\begin{array}{l}\text { Pembentukan } \\
\text { dan pengusulan } \\
\text { penetapan wilayah } \\
\text { hutan produksi dan } \\
\text { hutan lindung }\end{array}$ & $\begin{array}{l}\text { Pengusulan } \\
\text { pembentukan } \\
\text { wilayah hutan } \\
\text { produksi dan hutan } \\
\text { lindung }\end{array}$ \\
\hline $\begin{array}{l}\text { 3. Institusi wilayah } \\
\text { pengelolaan hutan }\end{array}$ & Pelaksanaan penetapan & Pertimbangan teknis & $\begin{array}{l}\text { Pengusulan } \\
\text { pembentukan }\end{array}$ \\
\hline 4. Arahan pencadangan & Penetapan & & \\
\hline 5. RPJ Panjang KPHP & $\begin{array}{l}\text { Penetapan norma, } \\
\text { standar, prosedur } \\
\text { dan kriteria; dan } \\
\text { pengesahan }\end{array}$ & $\begin{array}{l}\text { Pertimbangan teknis } \\
\text { pengesahan }\end{array}$ & $\begin{array}{l}\text { Pertimbangan teknis } \\
\text { pengesahan }\end{array}$ \\
\hline 6. RPJ Menengah KPHP & $\begin{array}{l}\text { Penetapan norma, } \\
\text { standar, prosedur } \\
\text { dan kriteria; dan } \\
\text { pengesahan }\end{array}$ & $\begin{array}{l}\text { Pertimbangan teknis } \\
\text { pengesahan }\end{array}$ & $\begin{array}{l}\text { Pertimbangan teknis } \\
\text { pengesahan }\end{array}$ \\
\hline 7. RPJ Pendek KPHP & $\begin{array}{l}\text { Penetapan norma, } \\
\text { standar, prosedur dan } \\
\text { kriteria }\end{array}$ & Pengesahan & $\begin{array}{l}\text { Pertimbangan teknis } \\
\text { pengesahan }\end{array}$ \\
\hline
\end{tabular}

RPJ = Rencana Pembangunan Jangka, dibuat oleh KPH

diikutsertakan secara lebih intensif dalam proses perencanaan pembentukan KPH di daerahnya, bukan hanya sekedar dimintai pertimbangan teknis. Pengalaman sebelumnya menunjukkan bahwa kata "pertimbangan" seringkali bermakna bahwa diterima bisa tidak pun tidak masalah.

Peraturan perundang-undangan memang memberikan kewenangan kepada pemerintah pusat untuk menguasai secara eksklusif seluruh kawasan hutan. Namun secara ekologis keberadaan kawasan hutan sering kali tidak dapat sedemikian gampang dipisahkan dari kawasan bukan hutan. Di Kabupaten Luwu Utara misalnya, kawasan hutan yang umumnya berada dalam wilayah bertopografi curam dengan jenis tanah berpasir menjadi penentu keberlangsungan sentra produksi pertanian di daerah tersebut. Pemerintah Kabupaten Luwu Utara perlu diberi ruang yang cukup untuk terlibat dalam proses perencanaan pengelolaan kawasan hutan yang ada di daerahnya, agar dalam memanfaatkan hutan dan hasil hutan, tetap memperhatikan aspek keberlangsungan fungsi hutan sebagai sistem penyangga kehidupan.

\section{Perlunya Reorganisasi Kelembagaan}

Ketika sistem pemerintahan otoda diberlakukan, setiap kabupaten di Sulawesi Selatan membentuk lembaga setingkat dinas atau kantor untuk menangani urusan kehutanan di daerahnya. Pada tingkat provinsi, lembaga dinas kehutanan yang memang sudah ada sejak sebelum otoda masih ada dan menjalankan tugas fungsinya pada era otoda. Selain itu, kecuali Kanwil Kehutanan, semua Unit Pelaksana Teknis (UPT) Departemen Kehutanan di Sulawesi Selatan masih dipertahankan dan menjalankan tugas fungsi sesuai dengan tugas pokok dan fungsinya (tupoksi) masing-masing. Tahun 2004 Departemen Kehutanan juga membentuk Pusat Pengendalian Pembangunan Kehutanan Regional, yang mana wilayah Sulawesi masuk dalam regional IV. Banyaknya lembaga kehutanan tampaknya juga menjadi tantangan tersendiri dalam pembangunan kehutanan di daerah. Sekalipun misalnya tupoksi setiap lembaga dan tata hubungan kerjanya dengan lembaga lain 
sudah diatur dalam ketentuan, dalam prakteknya seringkali terjadi tumpang tindih, dan lemahnya koordinasi seringkali menjadi salah satu isu penting penyebab tidak efektifnya mengapa sampai saat ini berbagai permasalahan pengelolaan hutan seakan tidak kunjung dapat diselesaikan dan kerusakan hutan terus berlanjut.

Dengan adanya KPHyang disertai dengan organisasi dan kelembagaannya, maka semakin bertambah jumlah lembaga yang akan mengurusi hutan di daerah. Menarik untuk dipertanyakan, akankah permasalahan kehutanan lebih mudah diatasi dengan diperbanyaknya lembaga yang mengurusi hutan?

Dengan semakin banyaknya lembaga yang mengurusi obyek yang sama, "koordinasi" menjadi sangat penting. Namun dalam prakteknya, koordinasi hanyalah sebuah kata yang mudah diucapkan namun tidak mudah diimplementasikan. Di antara UPT Departemen Kehutanan yang ada di Sulawesi Selatan saat ini pun tidak mudah diadakan koordinasi. Sebagai contoh, dalam menyusun rencana rehabilitasi hutan dan lahan, apakah UPT Balai Pengelolaan Daerah Aliran Sungai (BPDAS) sudah mengacu pada hasil penelitian yang dilakukan oleh Balai Teknologi Pengelolaan Daerah Aliran Sungai (BTPDAS) dan Balai Penelitian Kehutanan yang ada di daerah tersebut?

Penambahan lembaga/organisasi yang mengurusi hutan tentunya berimplikasi terhadap jumlah sumberdaya manusia yang akan dipekerjakan untuk mengurus hutan. Terbentuknya dinas-dinas kehutanan tingkat kabupaten pada era otoda meningkatkanjumlah tenaga manusia, baik dikantor maupun di lapangan. Sebagai konsekuensinya, jumlah anggaran untuk operasional lembaga dan gaji staf untuk mengurus hutan pun meningkat. Ironisnya, sejalan dengan semakin banyaknya lembaga dan sumberdaya manusia yang dikaryakan untuk mengurus hutan pada era otoda, banyak laporan menyebutkan bahwa degradasi hutan justru meningkat drastis pada era tersebut ${ }^{12}$.

Sekalipun berpotensi memperbaiki sistem pengelolaan hutan di masa yang akan datang, $\mathrm{KPH}$ dan kelembagaannya perlu dibentuk dengan pertimbangan yang matang. Jumlah lembaga yang banyak tidak menjamin terciptanya sistem pengelolaan yang baik, namun sebaliknya justru menyebabkan semakin sulitnya koordinasi dan tumpang tindih tugas dan fungsi. Dengan diberikannya tugas dan fungsi yang cukup luas kepada KPH, apakah keberadaan UPT BPDAS di daerah masih diperlukan? Apakah tidak sebaiknya
UPT BTPDAS digabung saja dengan Balai Penelitian dan Pengembangan Hutan? Apakah pada tingkat kabupaten masih diperlukan lembaga kehutanan setingkat dinas? Dalam hal ini, perlu dipertimbangkan reorganisasi kelembagaan kehutanan secara menyeluruh sebelum $\mathrm{KPH}$ dibentuk, agar salah satu tujuan pembentukan $\mathrm{KPH}$, yaitu "efisien" dapat tercapai.

\section{Kedudukan Lembaga/ Organisasi KPH}

Dari sejumlah kebijakan yang ada menyangkut $\mathrm{KPH}$, belum ada pengaturan secara jelas bagaimana kedudukan lembaga KPH terkait dengan lembaga kehutanan yang sudah ada saat ini. Pasal 8 PP 6/2007 hanya mengatur bahwa pemerintah dan/ atau pemerintah provinsi dan/atau pemerintah kabupaten/kota sesuai dengan kewenangannya menetapkan organisasi KPH. Lebih jauh dinyatakan bahwa organisasi KPHK serta KPHL dan KPHP lintas provinsi ditetapkan oleh pemerintah pusat, organisasi KPHL dan KPHP lintas kabupaten/kota oleh pemerintah provinsi, dan KPHL dan KPHP di dalam wilayah kabupaten/kota oleh pemerintah kabupaten/kota. Apakah ini berarti bahwa lembaga $\mathrm{KPH}$ juga akan berjenjang sesuai dengan jenjang pemerintahan yang ada?

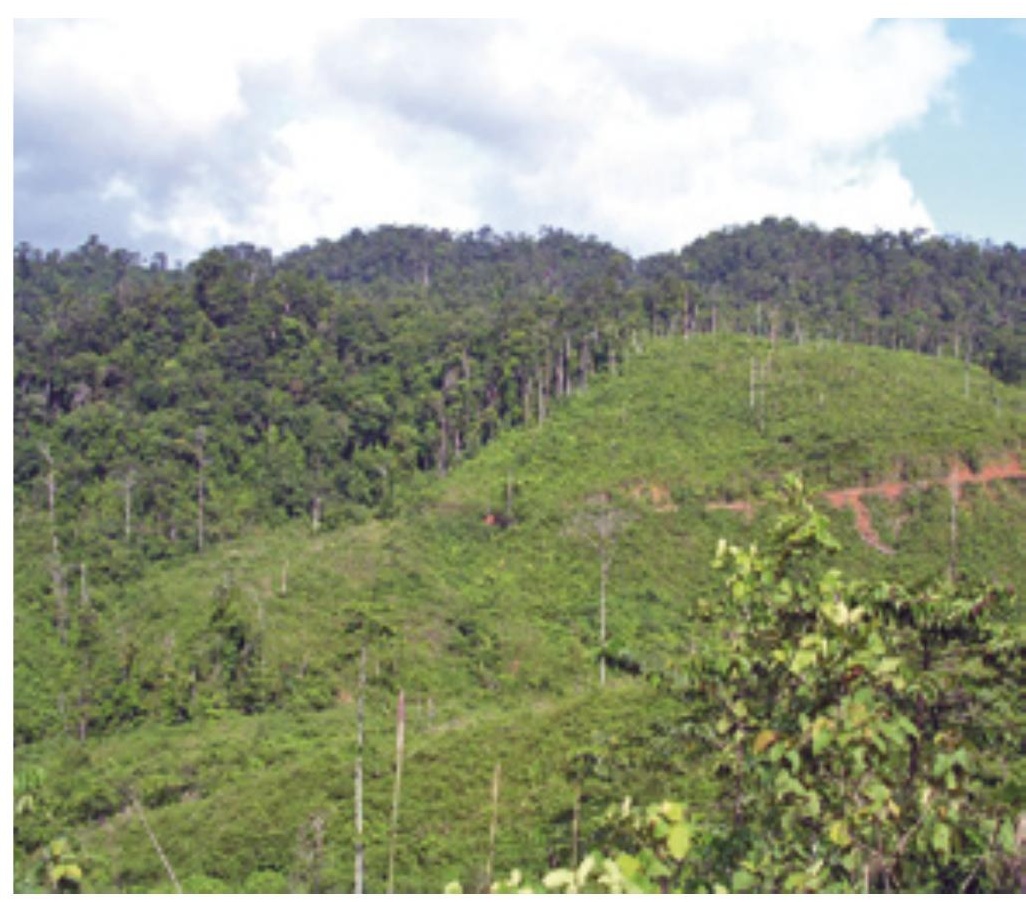

KPH menjadi bagian penting sistem pengurusan hutan nasional, provinsi dan kabupaten. Keterlibatan dan partisipasi penuh para pihak di daerah menentukan langkah-langkah keberhasilan menuju pengelolaan hutan lestari. 
Badan Planologi Departemen Kehutanan (2006) menyebutkan bahwa selain pada tingkat unit (KPHP, KPHL, KPHK), wilayah pengelolaan hutan juga akan dibentuk pada tingkat kabupaten/kota dan provinsi. Jika dikaitkan dengan bunyi Pasal 8 PP $6 / 2007$, pernyataan tersebut menunjukkan bahwa selain pada tingkat unit, lembaga $\mathrm{KPH}$ nampaknya juga akan ada pada tingkat kabupaten/kota (terbentuk dari himpunan unit-unit), pada tingkat provinsi (himpunan dari wilayah tingkat kabupaten/ kota dan unit-unit lintas kabupaten/kota) dan pada tingkat pusat (himpunan dari wilayah tingkat provinsi dan unit-unit lintas provinsi). Beberapa pertanyaan yang perlu dikaji antara lain: (1) milik siapa lembaga-lembaga pada setiap tingkatan tersebut; (2) apa nama dan bagaimana kedudukan antara satu lembaga KPH pada tingkatan yang berbeda; (3) bagaimana kedudukan lembaga $\mathrm{KPH}$ dengan lembaga kehutanan daerah yang ada dan UPT Departemen Kehutanan yang ada di daerah?

Munculnya pertanyaan „milik siapa“ terkait dengan pertanyaan lanjutan „siapa yang akan bertanggung jawab membayar dan melaksanakan tugas lembaga tersebut dan kepada siapa lembaga tersebut mempertanggungjawabkan kinerjanya? Apakah lembaga tingkat kabupaten akan diselenggarakan oleh pemerintah kabupaten, tingkat provinsi oleh pemerintah provinsi, dan tingkat pusat oleh pemerintah pusat? Jika demikian, siapa yang bertanggung jawab menyelenggarakan operasional $\mathrm{KPH}$ tingkat unit?

Pertanyaan kedua muncul terkait dengan koordinasi antara lembaga $\mathrm{KPH}$ pada tingkat pemerintahan yang berbeda. Jika tanggung jawab penyelenggaraan operasional $\mathrm{KPH}$ berada pada tingkat pemerintahan dimana lembaga tersebut berada (kabupaten, provinsi atau pusat), maka logikanya mereka mempertanggungjawabkan kinerjanya kepada kepala pemerintahan pada tingkatan tersebut. Tidak adanya garis komando secara langsung dari lembaga KPH pusat, provinsi dan kabupaten diduga akan mempersulit koordinasi dan konsultasi.

Belum jelasnya kedudukan lembaga $\mathrm{KPH}$ baik tingkat kabupaten, provinsi dan pusat terhadap lembaga kehutanan daerah dan UPT Departemen Kehutanan yang ada di daerah terkait erat dengan pembagian tugas dan fungsi. Dengan diberikannya tugas dan fungsi yang cukup luas kepada $\mathrm{KPH}$ tingkat unit ${ }^{13}$, maka perlu dilakukan pengaturan pembagian tugas dan fungsi lembaga-lembaga yang ada, terutama UPT pemerintah pusat di daerah yang selama ini banyak disoroti sebagai tidak sesuai dengan semangat otoda.

\section{Pendanaan Operasional}

Pasal 10 ayat (2) PP 6/2007 dan Peraturan Kepala Baplan Kehutanan ${ }^{14}$ mengatur pendanaan $\mathrm{KPH}$. Dinyatakan bahwa sumber dana bagi pembangunan $\mathrm{KPH}$ adalah dari APBN dan atau APBD provinsi dan atau APBD kabupaten/kota. Apakah ketentuan ini berarti bahwa dana untuk pembentukan KPH lintas provinsi dan operasional lembaganya akan bersumber dari APBN, KPH lintas kabupaten/kota bersumber dari APBD provinsi, dan yang dalam wilayah kabupaten/kota bersumber dari APBD kabupaten/kota?

Pada era otoda, daerah dituntut untuk sedapat mungkin mandiri dalam pembiayaan penyelenggaraan pemerintahan dan pembangunan di daerahnya. Tuntutan tersebut mendorong setiap daerah berupaya meningkatkan PADnya dan seringnya terjadi negosiasi yang ketat dalam penetapan proporsi perimbangan keuangan serta dalam penetapan dana alokasi umum antara pusat dan daerah. Dalam kaitannya dengan hal itu, pembebanan pembiayaan KPH kepada APBN dan atau APBD tentunya akan berimplikasi pada bagaimana nantinya pembagian manfaat dari hutan antara pemerintah pusat dan daerah. Sejak awal perlu dipikirkan sistem perimbangan pendapatan yang diperoleh dari KPHK serta KPHP dan KPHL yang pembentukan dan operasionalnya dibiayai oleh pemerintah pusat, provinsi dan kabupaten/ kota. Alangkah tidak adil jika hasil penerimaan dari pengelolaan hutan oleh $\mathrm{KPH}$ yang dibentuk dan dibiayai oleh pemerintah pusat, provinsi dan kabupaten diperimbangkan dengan proporsi yang sama. Sistem perimbangan sebagaimana selama ini ditetapkan terhadap penerimaan IHPH, PSDH dan $\mathrm{DR}^{15}$ mungkin perlu ditinjau kembali.

Pasal 13 dari Peraturan Ketua Badan Planologi Departemen Kehutanan mengarahkan agar organisasi KPH mampu membiayai diri sendiri dengan mengelola potensi yang ada. Mengingat perwilayahan $\mathrm{KPH}$ dibeda-bedakan berdasarkan fungsi pokok dan peruntukan kawasan hutannya, maka akan ada perbedaan kemampuan membiayai diri diantara KPHP, KPHL dan KPHK. Karena dimungkinkan untuk melakukan pemanfaatan sumberdaya hutan secara lebih leluasa, lembaga KPHP tentunya akan memiliki kemampuan yang lebih baik untuk membiayai operasionalnya sendiri dari pada KPHL dan KPHK. 


\section{Perwilayahan KPH}

Sampai saat ini baru KPHP yang sudah ditetapkan kriteria dan standar pembentukannya. Kriteria dan standar pembentukan KPHL dan KPHK masih dalam bentuk draf (Badan Planologi Departemen Kehutanan, 2006) ${ }^{16}$. Namun, tampaknya terdapat inkonsistensi dalam perwilayahan KPH. Di satu sisi, terdapat 4 prinsip yang dijadikan dasar penetapan kriteria dan standar pembentukan $\mathrm{KPH}$, yang salah satunya menyangkut ekologi/ekosistem. Di sisi lain, perwilayahan KPHP atau KPH secara umum dibuat mengacu pada sistem pembagian hutan menurut fungsi pokok dan peruntukannya, yang lebih didasarkan pada karakteristik fisik areal seperti kelerengan, jenis tanah dan curah hujan. Jika pendekatan ekologi menjadi dasar pembentukan $\mathrm{KPH}$, maka seharusnya hutan produksi, hutan lindung dan konservasi dikelola dalam satu kesatuan menurutbatas-batasmicroecoregion, misalnya suatu DAS. Keterkaitan dan keseimbangan antara satu fungsi pokok dengan lainnya akan terjaga dengan baik jika pengelolaannya tidak dipisah-pisahkan. Walaupun berdasarkan biogeofisik kawasan hutan dibedakan fungsi dan peruntukannya, namun sebagai sebuah kesatuan ekosistem hutan tidak
terpisahkan.Untukmewujudkanmodel pengelolaan hutan secara berkelanjutan (lestari), aspek biologi dan keanekaragaman hayati sebagai komponen ekosistem - yang tampaknya kurang disinggung dalam pedoman pembentukan KPHP yang sudah ada - seharusnya juga menjadi pertimbangan dalam pembentukan wilayah KPH.

Perwilayahan KPH akan erat kaitannya dengan kelembagaan dan pembiayaan operasional lembaganya. Makin banyak wilayah-wilayah $\mathrm{KPH}$ maka akan semakin banyak pula lembaganya, yang pada akhirnya memiliki konsekuensi pada besarnya dana yang dibutuhkan untuk membiayai operasionalnya. Sehubungan dengan hal itu, untuk dapat mencapai tujuan $\mathrm{KPH}$ yang adalah "terselenggaranya kegiatan pengelolaan hutan secara efisien dan lestari", maka perwilayahan KPH seharusnyajugadibuatdengan mempertimbangkan aspek efisiensi. Penggabungan pengelolaan kawasan hutan produksi dengan hutan lindung dan hutan konservasi dalam bentuk satu KPH memungkinkan terjadinya efisiensi pengelolaan.

Hal lain yang seharusnya juga dijadikan pertimbangkan oleh pemerintah pusat dalam membuat kriteria standar pembentukan wilayah

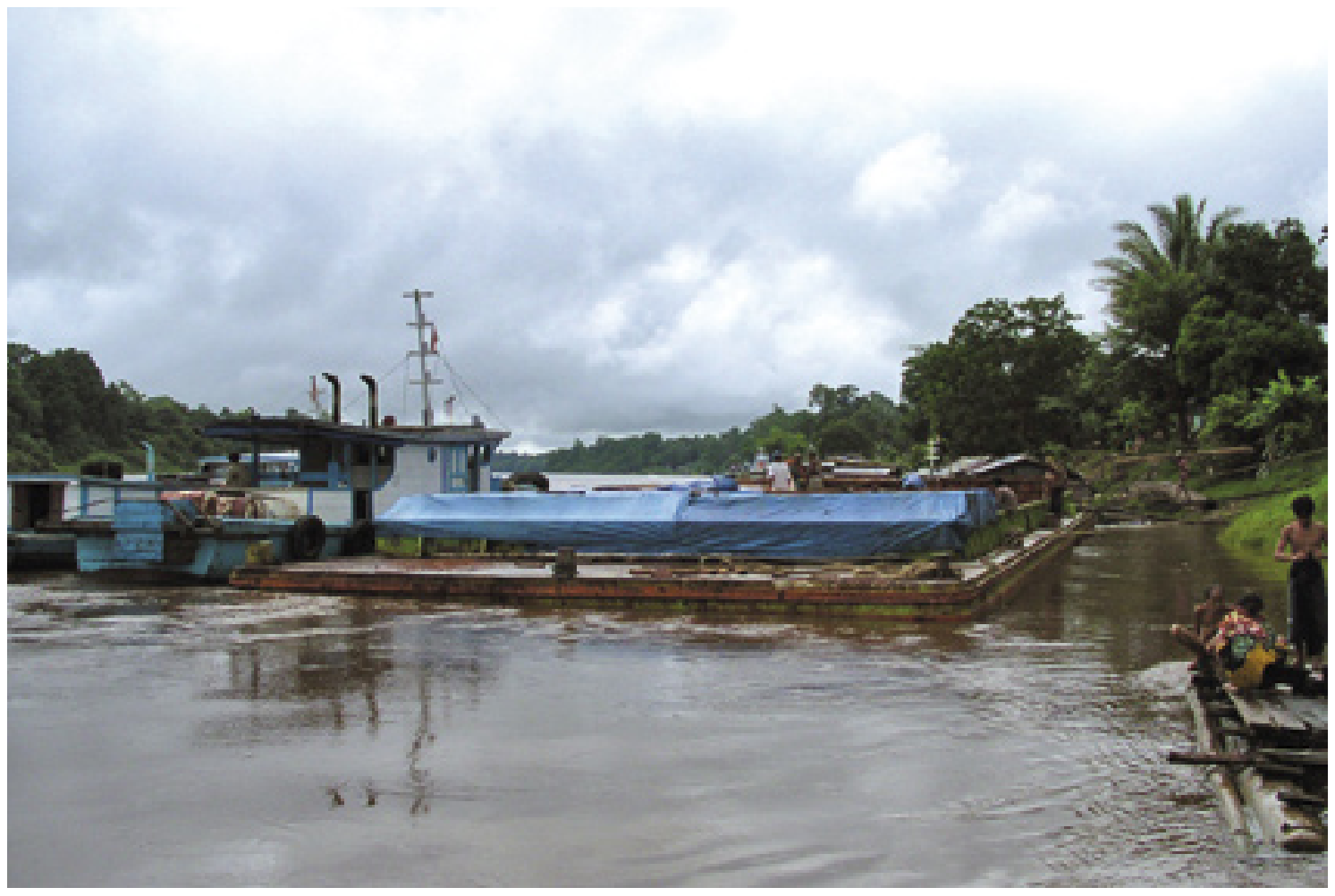

Hutan yang dikelola secara lestari menjadi sumber berkelanjutan bahan baku bagi industri kehutanan, yang akan meningkatkan perekonomian nasional, menjaga lingkungan dan ekosistem dan menyediakan sumber kehidupan bagi masyarakat di sekitarnya 
KPH adalah harapan bahwa KPH nantinya dapat membiayai dirinya sendiri. Apabila perwilayahan dan kelembagaan dipisah-pisahkan menurut fungsi pokok dan peruntukan kawasan hutannya, maka akan ada KPH yang mampu membiayai dirinya secara berlebih dan ada KPH yang operasionalnya defisit. Bukan tidak mungkin KPHL dan KPHK yang pengelolaannya lebih diarahkan pada sistem penyangga kehidupan akan dianaktirikan karena tidak mampu menghasilkan pendapatan sebesar yang dapat dihasilkan oleh KPHP. Sebenarnya indikasi ini sudah nampak dengan belum dikeluarkannya pedoman tentang kriteria dan standar pembentukan KPHL dan KPHK sampai saat ini, padahal pedoman tentang kriteria dan standar pembentukan KPHP sudah ditetapkan pada bulan Juli 2003.

Kawasan hutan dengan perbedaan fungsi pokok dan peruntukan sebenarnya saling terkait dan perlu dikelola secara terpadu. Alangkah ironis ketimpangan pengelolaan hutan yang terjadi selama ini, dimana di satu sisi begitu sulit untuk menyediakan anggaran bagi pengamanan kawasan hutan konservasi, tetapi di sisi lain di dalam kawasan hutan produksi wajib dibentuk blok konservasi plasma nutfah. Sebaliknya kawasan konservasi ditekan untuk mampu menghasilkan pendapatan bagi pengelolaannya sendiri. Oleh karena itu, perwilayahan $\mathrm{KPH}$ yang dibuat menurut fungsi pokok dan peruntukan kawasan hutannya berarti melanggengkan ketidaksinkronan sistem pengelolaan hutan mulai dari tingkat makro sampai ke tingkat unit $\mathrm{KPH}$.

Mengingat eratnya keterkaitan antara kawasan hutan dengan fungsi dan status yang berbeda sebagai satu kesatuan ekosistem yang sama, wilayah kesatuan ekosistem atau wilayah DAS seharusnya dijadikan pertimbangan utama dalam penetapan perwilayahan $\mathrm{KPH}$. Kawasan hutan produksi seharusnya dikelola dalam satu organisasi $\mathrm{KPH}$ dengan kawasan hutan lindung dan hutan konservasi melalui sistem pembiayaan subsidi silang. Penerimaan yang diperoleh dari memanfaatkan hutan produksi sebagian harus digunakan untuk mengurusi hutan lindung dan hutan konservasi yang ada di wilayah $\mathrm{KPH}$ bersangkutan karena berfungsi sebagai sistem penyangga kehidupan. Dengan demikian, di dalam kawasan hutan produksi tidak perlu lagi dibuat blok perlindungan plasma nutfah.

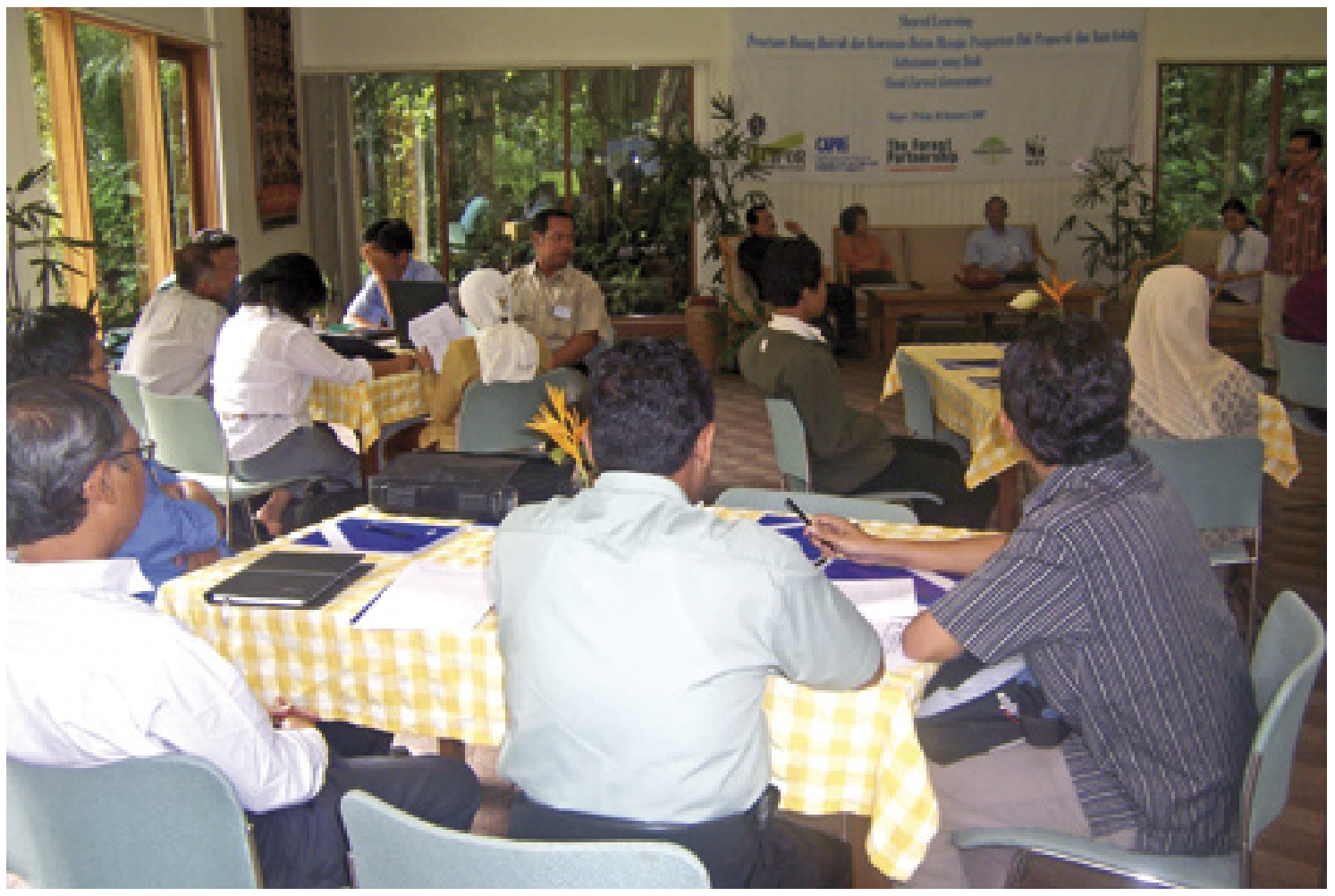

KPH dibentuk berdasar prinsip keterbukaan, pelibatan berbagai pihak, akuntabilitas dan ekosistem. Interaksi yang intensif antara para pihak di pusat dan daerah untuk berdiskusi dan saling bertukar pengalaman berpotensi membangun pemahaman bersama dan saling percaya 


\section{Kesiapan Daerah}

Untuk mempercepat terwujudnya sistem pengelolaan hutan model $\mathrm{KPH}$, Departemen Kehutanan secara terus menerus berupaya menyiapkan perangkat aturan perundangundangan serta pedoman kriteria dan standar pembangunan KPH. Namun demikian, upaya tersebut nampaknya tidak sejalan dengan langkah kesiapan pemerintah daerah. Walaupun sampai tahun 2006 diketahui sudah 10 provinsi menyelesaikan rancang bangun KPHPnya ${ }^{17}$ dan saat ini mungkin sudah banyak lagi daerah lainnya yang sudah mengikutinya, kunjungan ke beberapa daerah menunjukkan bahwa pejabat di daerah yang ditunjuk untuk menangani proses pembentukan KPHP sepertinya belum sepenuhnya memahami konsep KPHP. Beberapa kabupaten bahkan mempertanyakan konsep $\mathrm{KPH}$ yang ditawarkan pemerintah pusat dan sebagian bersikap pesimis bahwa konsep tersebut tidak akan membuat sistem pengelolaan hutan di daerahnya semakin baik.

Masyarakat di daerah juga nampaknya memiliki cara sendiri dalam memahami konsep KPH. Seorang staf Dinas Hutbun Kabupaten Luwu Utara ${ }^{18}$ menyatakan bahwa, diterbitkannya PP 6/2007 dimanfaatkan oleh beberapa pihak yang tidak bertanggung jawab untuk memunculkan kekacauan urusan kehutanan di daerah tersebut. Dengan alasan mengacu pada aturan baru tersebut, sekalipun tidak jelas pasal berapa yang dijadikan acuan, masyarakat menyerobot dan mengkapling-kapling kawasan hutan masing-masing seluas 27 ha per orang.

Fenomena di atas memunculkan sebuah pertanyaan mendasar "benarkah semua pihak berupaya mewujudkan sistem pengelolaan hutan sesuai harapan yang tertuang dalam konsep $\mathrm{KPH}$ ?". Jangan sampai konsep KPH ditanggapi sebagai tidak lebih dari sekedar kesempatan untuk mengadakan proyek, yang mana tidak lagi mudah dilakukan sejak sistem Anggaran Berbasis Kinerja (ABK) diterapkan. Diperlukan kehati-hatian dalam menanggapi respon daerah terhadap konsep KPH. Pemerintah pusat sebaiknya mengadakan pengkajian dan pengujian kesungguhan pemerintah daerah untuk mengelola hutan yang ada di daerahnya berdasarkan konsep $\mathrm{KPH}$. Upaya mewujudkan sistem pengelolaan hutan lestari dalam bentuk KPH harus dihindarkan dari konspirasi oknum pemerintah pusat dan daerah untuk sekedar menggolkan proyek bagi kepentingan pribadi. Agar KPH benar-benar dapat berjalan sesuai dengan yang diharapkan, penerapannya tidak harus bertarget bahwa pada tahun tertentu seluruh kawasan hutan di Indonesia sudah harus dikelola berdasarkan sistem KPH. Perlu diterapkan pendekatan bertahap dan langkah memperluas ke daerah lain. Skala yang lebih besar dapat dibangun setelah dilakukan kajian dan pembelajaran terhadap keberhasilan dan kegagalan dari model awal dengan skala yang lebih kecil.

\section{Kesimpulan dan Rekomendasi}

Kesatuan Pengelolaan Hutan (KPH) merupakan sistem pengelolaan hutan yang cukup memberikan harapan bagi terciptanya pengelolaan hutan secara bertanggung gugat, efisien dan lestari di Indonesia. Melalui sistem $\mathrm{KPH}$, seluruh kawasan hutan di Indonesia akan dibagi ke dalam wilayah- yang masing-masing dilengkapi dengan institusi yang bertanggung jawab terhadap pengelolaannya mulai dari tata hutan dan penyusunan rencana pengelolaan, pemanfaatan hutan, penggunaan kawasan hutan, rehabilitasi hutan dan reklamasi, sampai pada perlindungan hutan dan konservasi alam. Dengan demikian, untuk setiap wilayah akan jelas siapa pengelolanya, bagaimana pengelolaannya, dan siapa yang harus diminta bertanggung jawab apabila terjadi penyimpangan dalam pengelolaannya. Namun demikian, diantara sejumlah kebijakan yang telah dikeluarkan untuk mengatur pembentukan dan pengelolaan $\mathrm{KPH}$, masih ada beberapa halyang perlu diperhatikan oleh pemerintah agar tujuan KPH - untuk menyediakan wadah bagi terselenggaranya kegiatan pengelolaan hutan secara efisien dan lestari - dapat dicapai.

Mengingat masih simpang siurnya pemahaman para stakeholder terhadap konsep $\mathrm{KPH}$, maka konsep ini masih perlu dimantapkan, diperjelas dan disosialisasikan secara lebih intensif. Perbedaan ketentuan dalam PP 6/2007 dengan PP 38/2007 terkait pembentukan wilayah hutan perlu segera diperjelas. Pemerintah daerah, terutama kabupaten, perlu diberikan ruang dan peran yang lebih luas mulai dari proses pembentukan KPH sampai pada penyusunan rencana pengelolaannya.

Hutan merupakan suatu kesatuan ekosistem yang tidak terpisah-pisahkan menurut peruntukan dan lokasinya yang ditetapkan menurut pertimbangan administrasi. Oleh karena itu, untuk dapat mencapai tujuan utama KPH yang adalah efisien dan lestari, pembentukan wilayah KPH seharusnyalah tidak didasarkan pada fungsi pokok yang ditetapkan semata-mata atas pertimbangan tata air dan lokasi administrasi. Secara ekologi, hutan lindung, 


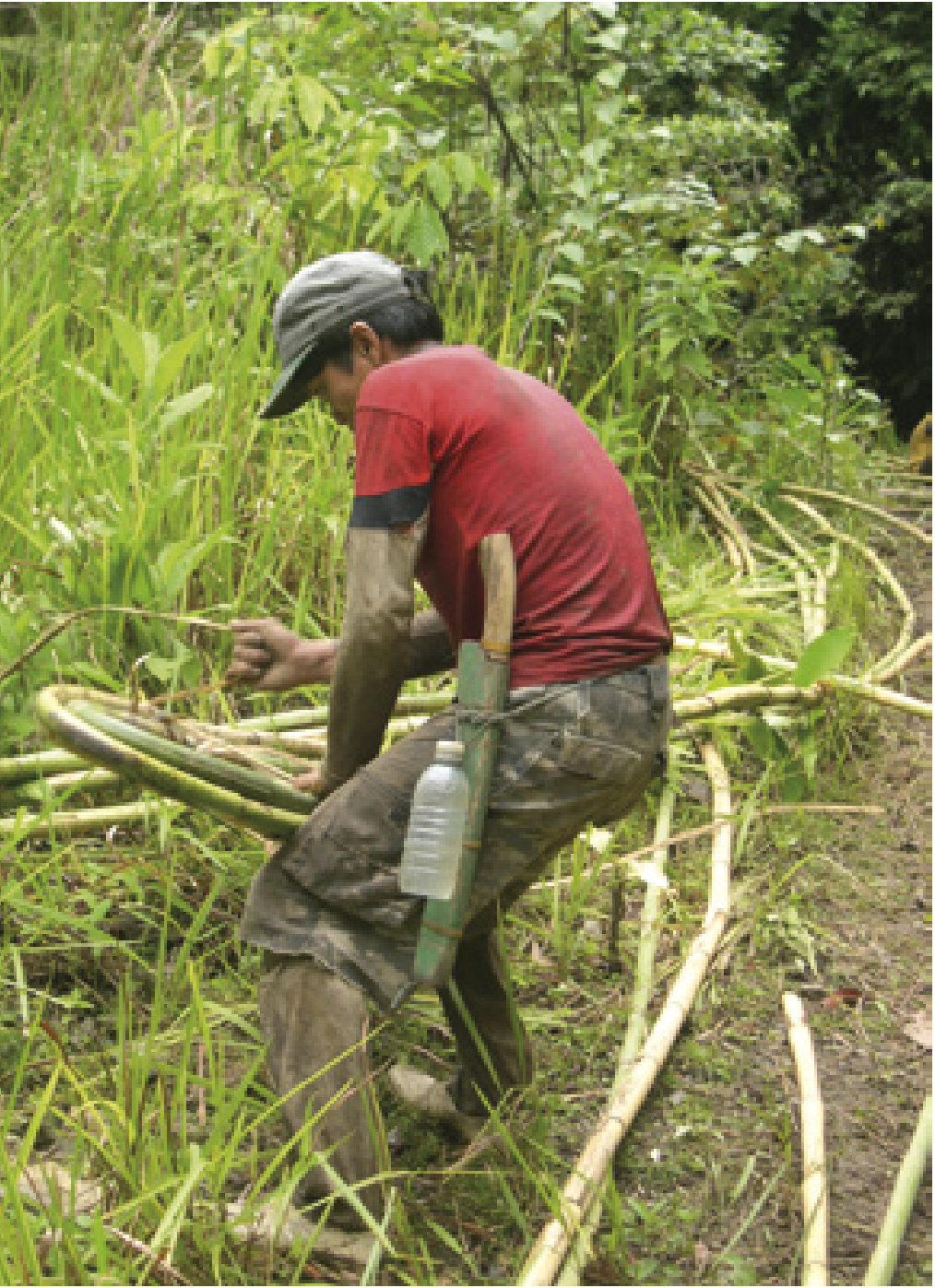

Manfaat sumberdaya hutan harus terdistribusi secara adil. Terbentuknya kesatuan pengelolaan hutan selayaknya tidak memutuskan akses masyarakat yang ketergantungan hidupnya sangat tinggi terhadap hutan

hutan konservasi dan hutan produksi yang lokasinya berdekatan dapat merupakan satu kesatuan ekosistem yang fungsinya satu sama lain saling melengkapi. Dari sisi pengelolaan, perwilayahan $\mathrm{KPH}$ yang tersekat-sekat menurut fungsi kawasan hutannya berarti mempertahankan sistem perwilayahan hutan yang berlaku selama ini yang ternyata gagal mewujudkan kelestarian hutan. Bertambahnya lembaga pengelola justru bertentangan dengan tujuan pembentukan $\mathrm{KPH}$ itu sendiri yakni efisien. Pemisahan wilayah $\mathrm{KPH}$ menurut fungsi kawasan hutannya juga dapat memunculkan kecemburuandiantarapengelolanya, karena nantinya akan ada KPH yang "basah" (KPHP) dan ada KPH yang "kering" (KPHL dan KPHA). Perwilayahan KPH menurut microecoregion-nya akan menjadikan wilayah suatu $\mathrm{KPH}$ terdiri dari berbagai fungsi hutan dengan sedikit lembaga pengelola, sehingga pengelolaannya akan efisien.

Untukmenghindaritumpang tindih tugas dan fungsi lembaga kehutanan yang sudah cukup banyak saat ini, dengan munculnya lembaga $\mathrm{KPH}$ mulai dari tingkat unit, kabupaten, provinsi dan pusat, maka kelembagaan kehutanan perlu direorganisasi secara menyeluruh. Secara radikal upaya ini mungkin akan mencakup keputusan untuk menghilangkan institusi yang memang tidak perlu ada. Dinas kehutanan daerah mungkin tidak diperlukan lagi atau perlu direstrukturisasi mengingat sudah ada lembaga $\mathrm{KPH}$ yang diberi tugas fungsi yang sangat luas (Pasal 9 PP 6/2007) pada tingkat provinsi dan kabupaten. Sama halnya dengan dinas kehutanan daerah, beberapa UPT Departemen Kehutanan yang tugas fungsinya sudah dapat dijalankan oleh lembaga $\mathrm{KPH}$, mungkin tidak diperlukan lagi. Selanjutnya, kedudukan serta pembagian tugas, fungsi dan kewenangan diantara lembaga $\mathrm{KPH}$ yang ada dan antara lembaga KPH dengan lembaga kehutanan lainnya baik lembaga daerah maupun UPT pusat, perlu diatur secara tegas.

Staf yang kehilangan jabatan setelah dilakukan reorganisasi dan restrukturisasi kelembagaan kehutanan dapat ditampung di lembaga $\mathrm{KPH}$. Kantor pengelola KPH sebaiknya berlokasi di dalam wilayah KPH itu sendiri, bukan di ibukota kabupaten. Dengan demikian pengelola KPH dapat setiap hari berinteraksi dengan dan melihat langsung wilayah hutan yang dikelolanya. Terkait dengan pembagian urusan pendanaan operasional dan pembagian manfaat pengelolaan KPH antara pemerintah pusat dan daerah, sebaiknya sejak dini sudah dibuatkan aturan mainnya secara jelas dan tegas.

Dengan mempertimbangkan berbagai aspek dan pandangan dari para stakeholder, model perwilayahan KPH yang sudah dibakukan saat ini sebaiknya dikaji kembali agar tujuan pembentukan $\mathrm{KPH}$ yang adalah efisien dan lestari benar-benar dapat terwujud. KPH perlu dibentuk berdasarkan keterkaitan komponen ekosistem dan tidak dipisah-pisahkan menurut fungsi pokok dan peruntukannya.

\section{Daftar Acuan}

Badan Planologi Kehutanan. 2006. Buku Pintar Bidang Planologi Kehutanan. Badan Planologi Departemen Kehutanan, Jakarta. 


\section{Catatan Akhir}

1 PP No. 6 Tahun 2007 Tentang Tata Hutan dan Penyusunan Rencana Pengelolaan Hutan serta Pemanfaatan Hutan.

2 UU No. 5 Tahun 1967 Tentang Ketentuanketentuan Pokok Kehutanan (khususnya Pasal 10).

3 Bagian kelima yang menyangkut Pembentukan Wilayah Pengelolaan Hutan (Pasal 17).

4 Misalnya, ODA dengan dukungan Pemerintahan Inggris dengan lokasi modelnya di Jambi dan Kalimantan Tengah, dan Swedforest International/ PT Wahanabhakti Persadajaya dengan lokasi modelnya di Kalimantan Timur.

5 Sebagai instrumen menuju pengelolaan hutan yang lestari dan efisien, HPH juga merupakan $\mathrm{KPH}$ dalam arti "kesatuan pengusahaan" (seperti disebutkan dalam Pasal 10 UU 5/67 tentang Undang Undang Pokok Kehutanan). Namun, jika mengacu pada kriteria pembentukan $\mathrm{KPH}$, wujud HPH tampaknya tidak bisa dianggap $\mathrm{KPH}$, misal karena delineasi batasnya seringkali tidak mempertimbangkan batas alam dan faktor ekologi.

6 Keputusan Menteri Kehutanan No. 230/ Kpts-II/2003 Tentang Pembentukan Kesatuan Pengelolaan Hutan Produksi.

7 IUPK: Izin Usaha Pemanfaatan Kawasan, IUPJL: Izin Usaha Pemanfaatan Jasa Lingkungan, IUPHHBK: Izin Usaha Pemanfaatan Hasil Hutan Bukan Kayu, IPHHK: Izin Pemungutan Hasil Hutan Kayu. Untuk Izin Pemungutan Hasil Hutan Bukan Kayu (IPHHBK) tidak diatur mengenai pemberian izin lintas provinsi.

8 Salah satu pasalnya berbunyi organisasi $\mathrm{KPH}$, baik dalam satu wilayah maupun lintas kabupaten, dibentuk berdasarkan standar kriteria yang ditetapkan oleh pemerintah pusat (Pasal 8 [5] dan [6]).

9 Bunyi ketentuan ini juga ditemukan pada PP No. 34/2002 ataupun yang menggantikannya, PP 6/2007. Komitmen pemerintah pusat untuk melimpahkan kewenangan tersebut sebetulnya sudah ada sejak lama. Namun demikian, tampaknya tidak ada upaya yang konkret dari pemerintah pusat untuk menyusun suatu kriteria dan indikator tentang daerah yang siap kelembagaan dan visinya; dan untuk melakukan pembinaan ke arah tersebut. Demikian pula halnya dengan pemerintah daerah yang kurang menunjukkan kesiapannya.

10 PP No. 38 Tahun 2007 Tentang Pembagian Urusan Pemerintahan antara Pemerintah, Pemerintahan Daerah Provinsi, dan Pemerintahan Daerah Kabupaten/Kota.

11 Pasal 16 ayat (4) Keputusan Menteri Kehutanan No. 230/Kpts-II/2003 tentang Pembentukan Kesatuan Pengelolaan Hutan Produksi.

12 Misalnya seperti digambarkan dalam Barr, C., I.A. Resosudarmo, A. Dermawan, and B. Setiono. 2006. Decentralization's Effects on Forest Concessions and Timber Production. In: Decentralization of Forest Administration in Indonesia. Center for International Forestry Research.

13 Pasal 9 ayat (1) PP 6/2007.

14 Pasal 17 Peraturan Kepala Badan Planologi Kehutanan No: SK. 80/VII-PW/2006 tentang Pedoman Pembangunan Kesatuan Pengelolaan Hutan (KPH) Model.

15 Iuran Hak Pengusahaan Hutan (IHPH), Provisi Sumber Daya Hutan (PSDH) dan: Dana Reboisasi (DR).

16 Berdasarkan hasil wawancara dengan staf Departemen Kehutanan (Oktober 2007), diketahui bahwa saat ini Departemen Kehutanan tengah menyelesaikan beberapa peraturan pelaksanaan PP 6/2007 terkait dengan pedoman pembentukan $\mathrm{KPH}$, pembentukan organisasi dan penyusunan rencana pengelolaan. Direncanakan juga pedoman KPH Lindung dan KPH Konservasi akan digabungkan dalam satu pedoman dengan KPH Produksi, yang sudah diterbitkan lebih dahulu.

17 Badan Planologi Departemen Kehutanan (2006) menyebutkan bahwa sampai tahun 2004 setidaknya sudah 10 provinsi di luar Jawa yang telah selesai disusun rancang bangun dan peta arahan pencadangan KPHPnya (Sumatera Utara, Sumatera Selatan, Kalimantan Barat, Kalimantan Selatan, Sulawesi Utara, Sulawesi Tengah, Sulawesi Tenggara, Bali, Nusa Tenggara Barat dan Irian Jaya).

${ }^{18}$ Berdasarkan hasil wawancara pada Bulan Agustus 2007. 
Tulisan ini merupakan bagian dari penelitian berjudul "Can Decentralization Work for Forests and the Poor? Policy research to promote sustainable forest management, equitable economic development, and secure local livelihoods in Indonesia", yang merupakan kerjasama antara CIFOR, Universitas Hasanuddin, the Australian National University (ANU) dan Pemerintah Kabupaten Luwu Utara, Provinsi Sulawesi Selatan. Penelitian didanai oleh ACIAR (Australian Center for International Agriculture Research). Disclaimer: Isi tulisan sepenuhnya menjadi tanggungjawab para penulis dan tidak mencerminkan pandangan CIFOR, lembaga mitra dan donor.
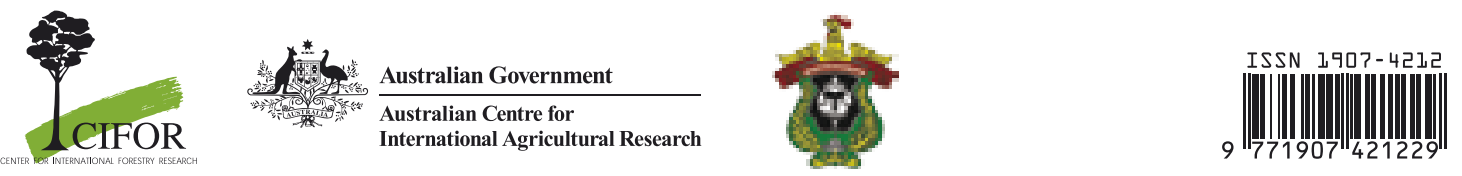

Center for International Forestry Research, CIFOR

Office address: Jalan CIFOR, Situ Gede, Sindang Barang Bogor

Tel: +62(251) 622622 Fax: +62(251) 622100

E-mail: cifor@cgiar.org

Website: www.cifor.cgiar.ors

Barat 16680 , Indonesia

Mailing address: P.O. Box. 6596 JKPWB

Jakarta 10065, Indonesia

Foto oleh Gusti Z. Anshari, Adnan Hasantoha dan

Ngakan Putu Oka

Forests and Governance Programme di CIFOR mengkaji cara pengambilan dan pelaksanaan keputusan berkenaan dengan hutan dan masyarakat yang hidupnya bergantung dari hutan. Tujuannya adalah meningkatkan peran serta dan pemberdayaan kelompok masyarakat yang kurang berdaya, meningkatkan tanggung jawab dan transparansi pembuat keputusan dan kelompok yang lebih berdaya dan mendukung proses-proses yang demokratis dan inklusif yang meningkatkan keterwakilan dan pengambilan keputusan yang adil di antara semua pihak. 